\title{
Reliability of Precipitation Measurements as Related to Exposure
}

\author{
Merle J. Brown ${ }^{1}$ and Eugene L. Peck ${ }^{2}$ \\ U.S. Weather Bureau \\ (Manuscript received 3 November, in revised form 12 January 1962)
}

\begin{abstract}
A subjective classification system was developed to evaluate the reliability of measurements of precipitation occurring primarily as snow in relation to the exposure of the gage. This system was used in classifying 30 sites above $8,000 \mathrm{ft}$ in Utah where both precipitation measurements and snow surveys are made. A comparison of the winter precipitation (October-March) with the water equivalent of the snow on the ground as of 1 April showed that the differences in amounts were related to the exposure classifications. Data on dual installation of precipitation gages at protected and unprotected sites are given. The protection afforded by the installation of a windshield where light winds are observed is also illustrated.
\end{abstract}

\section{Introduction}

Climatological data are continually being put to greater use in solving the multiplicity of hydro-meteorological problems associated with the development of water resources. As the world population continues to mushroom, the need for more efficient use of our water supply becomes increasingly apparent. To realize maximum value from climatological records, it is essential that we understand the limitations of the records. Very few research studies have been conducted on the reliability of basic data and our present knowledge on this subject is rather limited. This paper focuses attention on one of the problems inherent in the collection of precipitation data, i.e., the reliability of precipitation measurements as related to gage exposure.

\section{Gage exposure}

Only a few users of precipitation data have an adequate knowledge of the exposure at gage sites, although such information is very important in the evaluation of precipitation records. It has been shown that the reliability of precipitation measurements at a given location is related to the amount of wind action on the gage during periods of precipitation, especially when the precipitation is in the form of snow (Wilson, 1954; Alter, 1937; Black, 1954; and Bruce and Potter, 1957)..$^{3}$

\footnotetext{
1 Pacific Area Climatologist, Honolulu, Hawaii.

${ }^{2}$ Hydrologist in Charge, Water Supply Forecast Unit, Salt Lake City, Utah.

${ }^{3}$ Corps of Engineers, 1956: Snow hydrology. Summary Report of the Snow Investigations, North Pacific Division, Corps of Engineers, U. S. Army, Portland, Oreg., 53-69.
}

\section{Precipitation measurements}

It is essential to have an understanding of what precipitation records represent for an appreciation of the value of such records. It might be asked if the records represent (a) the total amount of precipitation which falls from the sky as a result of meteorological processes, (b) the amount of moisture that accumulates on the ground or, (c) an index to one of the above. Wilson. (1954) has shown that precipitation measurements from a gage properly protected from wind are a much more reliable index to the areal precipitation than if the gage is subject to wind effects during the period of precipitation. That is, the nearer the catch is to the true fall on the ground at the location, the better it is as an index to the areal precipitation. Unless the gage is situated such that drifting snow might accumulate in the gage or blow into the gage from nearby objects, it is believed that the larger the catch, the closer it represents the amount which actually fell at the site.

The fact that snow may blow away from the gage site after it has fallen does not mean that a precipitation catch less than the true fall, because of adverse wind effect, is a better indication of the precipitation on the ground. The total amount measured in the gage may be more comparable to the amount on the ground, since it is less than the true amount, but this does not indicate that it is a better index to the areal precipitation or even to the amount on the ground. Records from precipitation gages located so that they receive blowing snow from higher rocky ridges or peaks may be more directly comparable to the snow on the ground at the particular location. This does not necessarily mean that the reported catch represents the true precipitation. An example of such a condition is the 
record for Grinnell Glacier No. 2 in Montana. The gage is located near the foot of an active glacier and near a high rocky bluff. The catch as measured in the gage (annual average approximately 150 inches) is not indicative of the true precipitation nor is it a good index of the precipitation in the general area, but the total catch has been shown to be related to the runoff from the small glacier basin.

If precipitation records are to be used to develop isohyetal maps, then all records should reflect the same factor, that is, only the average amount of precipitation which falls as a result of meteorological processes. If detailed information on the exposure and description of each station is known, then consideration can be given to the value of the catches from different exposures.

\section{Evaluation of gage exposure}

At the present time, those working with precipitation records do not necessarily have the same understanding as to what constitutes a good or a poor exposure. Most agree that the best location is one which has some natural protection from adverse wind effects.

If some standards for gage exposure are to be established, it is necessary to consider many factors. For instance, some gage sites which are completely surrounded by objects which subtend angles of $20^{\circ}$ to $30^{\circ}$ may have excellent protection. Other sites which have objects in only some directions may or may not have adequate protection from the wind. Turbulence and eddy currents resulting from isolated objects upwind from the gage are generally considered undesirable.

Because of our limited knowledge of the relationship between the location, breadth, spacing and size of objects and the protection afforded a gage, it is not possible at the present time to arrive at an objective evaluation of exposure. One technique to assist in such an evaluation would be the use of the photocanopyometer as described by Codd (1959) to measure the angles from the gage to the tops of the nearby objects.

\section{Subjective classification of exposure}

Although the limitations of a subjective classification of gage exposure are recognized, it is believed that the use of such a classification system does have merit. Seven subjective classifications based on the degree of protection afforded by nearby objects and a knowledge of the general terrain are given below:

(A) Well-protecled. Sheltered in all directions by objects subtending angles of $20^{\circ}$ to $30^{\circ}$ from the gage orifice with none greater than $45^{\circ}$, and with objects of sufficient breadth to minimize eddy effects. The surrounding terrain should provide some protection from the general winds. An example of a well protected site is an open area in a large coniferous forest, where the vegetation provides maximum protection the year around. The gage should not be located so that strong winds would be funneled into the area by the surrounding terrain.

(B) Protected. Sheltered by the general terrain of the area but not fully protected from wind action on the gage by objects in the vicinity. The unprotected directions should not be in the general direction of the winds associated with precipitation.

(C) Fairly well-protected. May or may not be sheltered by the general terrain. Nearby objects provide some protection from winds associated with major storms. The precipitation catch would be reduced during snow storms with strong general winds.

(D) Moderately windy. Little protection by the general terrain. Nearby objects do not have the expanse or breadth to afford adequate protection from winds during periods of precipitation.

(E) Windy. Little or no protection from nearby objects but the location may have some protection afforded by the general terrain.

(F) Very windy. No protection from the general terrain, or the general terrain is such that the location is subject to stronger winds than found in the area. Little or no protection from nearby objects. Examples would be gages exposed on mountain tops or ridges or at the mouth or head of canyons where strong winds might be funneled to the site. Both "windy" and "very windy" locations have very open exposures. The difference is that a "very windy" location is subject to adverse effects because of the general terrain.

(G) Overprotected. One or more objects in the vicinity of the gage extending an angle of more than $45^{\circ}$ in the vertical, with that portion of the object or objects extending above $45^{\circ}$ having a horizontal angle greater than $10^{\circ}$.

\section{Precipitation catch and exposure classification}

In an effort to determine the effectiveness of the subjective classification system, measurements from precipitation gages and snow survey data at the same locations were analyzed. In Utah, there are several locations where precipitation gages are installed at snow courses of the Soil Conservation Service. The classification system was discussed with a group of meteorologists from the Salt Lake City Weather Bureau Offices who had inspected these precipitation gage sites. Each was requested to classify the exposure of the stations visited. Records from only those stations above $8000 \mathrm{ft}$ were used to avoid the effects of winter melt of the snow on the ground. Table 1 gives a listing of the stations with the classification as assigned independently by the meteorologists. October-March precipitation totals have been used for comparison with the 1 April water equivalent of the snow on the ground for each year of record, and these data are included in 
TABLE 1. October-March precipitation totals and water equivalent of snow on the ground for stations of various exposure classifications.

\begin{tabular}{|c|c|c|c|c|c|c|c|c|c|c|c|c|c|}
\hline $\begin{array}{c}\text { Station name } \\
\text { (Utah Stations) }\end{array}$ & $\begin{array}{l}\text { Exposure* } \\
\text { classification }\end{array}$ & $\begin{array}{l}1954 \\
1 \text { Apr } \\
\text { W.E. }\end{array}$ & $\begin{array}{l}-55 \\
\text { Oct- } \\
\text { Mar } \\
\text { pcpn. }\end{array}$ & $\begin{array}{l}1955 \\
1 \text { Apr } \\
\text { W.E. }\end{array}$ & $\begin{array}{l}-56 \\
\text { Oct- } \\
\text { Mar } \\
\text { pcpn. }\end{array}$ & $\begin{array}{l}1956 \\
1 \text { Apr } \\
\text { W.E. }\end{array}$ & $\begin{array}{l}-57 \\
\text { Oct- } \\
\text { Mar } \\
\text { pcpn. }\end{array}$ & $\begin{array}{l}195 \\
1 \text { Apr } \\
\text { W.E. }\end{array}$ & $\begin{array}{l}-58 \\
\text { Oct- } \\
\text { Mar } \\
\text { pcpn. }\end{array}$ & $\begin{array}{l}1958 \\
1 \text { Apr } \\
\text { W.E. }\end{array}$ & $\begin{array}{l}-59 \\
\text { Oct- } \\
\text { Mar } \\
\text { pcpn. }\end{array}$ & $\begin{array}{l}1959 \\
1 \text { Apr } \\
\text { W.E. }\end{array}$ & $\begin{array}{l}-60 \\
\text { Oct- } \\
\text { Mar } \\
\text { pcpn. }\end{array}$ \\
\hline Alpine Meadowst & Very windy & 22.1 & 16.7 & 24.0 & 19.9 & 32.4 & 24,2 & 32.8 & 30.4 & 20.7 & 15.7 & 23.0 & 19.8 \\
\hline Beaver Dams & Well protected & & & & & 14.7 & 15.2 & 16.3 & 19.6 & 9.4 & 10.4 & 12.4 & 13.8 \\
\hline Big Flat & Over protected & & & & & & & 27.3 & 28.9 & 11.7 & 11.7 & 16.8 & 16.8 \\
\hline Black Flat & Well protected & & & & & 10.0 & 12.9 & 15.8 & 18.6 & 7.8 & 9.5 & 11.8 & 15.0 \\
\hline Box Creek & Well protected & & & & & 14.2 & 14.6 & 17.4 & 20.8 & 8.6 & 10.0 & 12.2 & 15.1 \\
\hline Castle Valley & Well protected & & & & & 11.6 & 12.9 & 17.8 & 22.6 & 7.5 & 10.0 & 10.8 & 13.7 \\
\hline Chalk Creek \#2 & Fairly well protected & & & & & & & 14.5 & 15.3 & 15.0 & 15.4 & 9.9 & 11.8 \\
\hline Dry Bread Pond & Weil protected & & & & & 19.0 & 19.4 & 22.2 & 22.4 & 12.9 & 19.2 & 15.5 & 18.8 \\
\hline Duck Creek RS & Well protected & & & 9.6 & 12.4 & 16.6 & 16.2 & 18.7 & 26.9 & 7.2 & 12.8 & 8.2 & 4.2 \\
\hline Ephraim Hdqts. & Well protected & 15.0 & 16.5 & 13.7 & 16.3 & 23.8 & 22.0 & 20.8 & 23.9 & 15.4 & 13.1 & 14.0 & 16.1 \\
\hline Farnsworth Lake & Well protected & & & & & 21.6 & 19.2 & 22.8 & 27.1 & 10.9 & 13.2 & 19.3 & 21.7 \\
\hline Gooseberry RS & Well protected & & & & & 13.4 & 13.8 & 15.4 & 18.4 & 7.3 & 9.2 & 12.6 & 14.7 \\
\hline Gooseberry Res. & Windy & & & & & 23.5 & 17.9 & 24.1 & 25.0 & 16.6 & 15.3 & 17.1 & 15.7 \\
\hline Kimberly Mine & Well protected & & & & & 16.2 & 17.4 & 18.8 & 25.3 & 11.4 & 13.0 & 15.8 & 18.9 \\
\hline Klondike Narrows & Well protected & & & & & 22.3 & 23.1 & 24.3 & 27.0 & 17.8 & 19.8 & 18.0 & 21.7 \\
\hline Lake Fork Mtn. & Windy & 13.8 & 11.2 & 15.0 & 12.5 & 10.4 & 9.6 & 13.6 & 15.5 & 8.6 & 9.9 & 8.2 & 8.7 \\
\hline Mammoth RS & Windy & 17.7 & 13.6 & 18.8 & 19.1 & 23.0 & 18.6 & 24.8 & 23.6 & 16.6 & 15.6 & 17,2 & 14.6 \\
\hline Monte Cristo RS & Moderately windy & 26.9 & 22.1 & 31.6 & 30.7 & 25.7 & 22.0 & 31.5 & 25.6 & 20.0 & 21.9 & 19.9 & 18.2 \\
\hline Mount Baldy RS & Windy & 21.5 & 15.3 & 22.1 & 14.9 & 28.8 & 20.3 & 33.2 & 24.1 & 17.2 & 12.2 & 21.2 & 17.8 \\
\hline Paradise Park & Over protected \# & & & & & 11.0 & 10.3 & 12.8 & 17.1 & 7.9 & 8.9 & 7.2 & 9.0 \\
\hline Payson RS & Very windy & & & & & 21.0 & 17.6 & 23.0 & 21.5 & 14.4 & 14.8 & 17.8 & 16.6 \\
\hline Silver Lake & Well protected & 27.9 & 26.8 & 27.9 & 33.5 & 26.6 & 26.9 & 27.3 & 31.8 & 21.3 & 24.3 & 19.6 & 25.2 \\
\hline Soapstone RS & Well protected & & & & & 14.8 & 17.1 & 15.7 & 18.9 & 12.2 & 14.7 & 9.0 & 12.1 \\
\hline Strawberry Daniels & Well protected & 15.5 & 15.4 & 13.2 & 21.2 & 17.1 & 18.4 & 16.3 & 19.0 & 13.2 & 14.5 & 11.1 & 13.9 \\
\hline Strawberry Res & & & & & & & & & & & & & \\
\hline East Portal & Windy & 11.1 & 8.3 & 8.3 & 10.1 & 14.3 & 10.9 & 12.7 & 11.0 & 7.5 & 7.3 & 8.0 & 7.7 \\
\hline Stuart Guard Sta. & Well protected & & & & & 11.1 & 11.0 & 11.6 & 15.9 & 4.6 & 9.4 & 4.2 & 12.3 \\
\hline Timpanogos Divide & Fairly well protected & 27.8 & 23.3 & 27.2 & 31.6 & 24.8 & 23.8 & 31.6 & 28.4 & 14.2 & 15.4 & 18.5 & 18.4 \\
\hline Trial Lake & Over protected\# & & & & & 28.4 & 23.6 & 27.8 & 26.0 & 23.7 & 21.6 & 21.7 & 18.8 \\
\hline Webster Flat & Well protected & 14.7 & 13.0 & 11.0 & 13.5 & 15.8 & 16.4 & 22.1 & 29.6 & 11.6 & 15.1 & 13.8 & 18.1 \\
\hline White River \# 1 & Well protected & & & & & 15.0 & 15.0 & 14.8 & 16.5 & 8.8 & 9.9 & 8.2 & 11.2 \\
\hline
\end{tabular}

* Classification assigned by personnel who inspected or installed station. Made prior to time comparisons were known. \# In these two cases, tall trees have subtended angles of over $60^{\circ}$ and do not completely encircle the gage site.

† Additional years of record for Alpine Meadows:

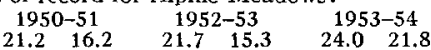

TABLE 2. October-March precipitation totals and water equivalent of snow on the ground for various exposure classifications.

\begin{tabular}{|c|c|c|c|c|c|}
\hline Classification & $\begin{array}{l}\text { Number of } \\
\text { seasonal dual } \\
\text { measurements }\end{array}$ & $\begin{array}{l}\text { Avg. } \\
\text { Oct-Mar } \\
\text { precipitation } \\
\text { (inches) }\end{array}$ & $\begin{array}{c}\text { Avg. } 1 \text { Apr } \\
\text { water equivalent } \\
\text { (inches) }\end{array}$ & $\begin{array}{c}\text { Difference, } \\
\text { Oct-Mar precipitation } \\
\text { minus } 1 \mathrm{Apr} \\
\text { water equivalent }\end{array}$ & $\begin{array}{c}\text { Per cent excess or } \\
\text { deficiency (Oct-Mar } \\
\text { precipitation compared } \\
\text { with } 1 \text { Apr } \\
\text { water equivalent) }\end{array}$ \\
\hline Well-protected & 77 & 17.5 & 15.0 & 2.5 & +17 \\
\hline Fairly well-protected & 9 & 20.4 & 20.4 & 0.0 & 0 \\
\hline Moderately windy & 6 & 23.4 & 25.9 & -2.5 & -10 \\
\hline Windy & 26 & 15.1 & 17.7 & -2.6 & -15 \\
\hline Very windy & 13 & 19.3 & 22.9 & -3.6 & -16 \\
\hline Over-protected & 11 & 17.5 & 17.8 & -0.3 & -2 \\
\hline
\end{tabular}

Table 1. It is recognized that these two values are not necessarily equivalent since some of the precipitation may be in the form of rain and/or the snow pack might lose some water during the winter. There is also the possibility that the snow pack might gain additional water by drifting snow and/or from sublimation.

Table 2 is a tabulation of the number of cases for each exposure classification and the average of the
October-March precipitation totals minus the 1 April water equivalent of the snow on the ground.

A relatively good relationship is evident between the exposure classification and the differences of the October-March precipitation and the April 1st water equivalent of the snow on the ground. The average for the well-protected sites shows that the OctoberMarch precipitation at such locations is generally 
greater than the 1 April water equivalent. For those exposure classifications indicating adverse wind effects, the October-March precipitation totals were lower than the 1 April water equivalents. Although the number of cases used in this study was limited, the results tend to verify the value of the subjective exposure classifications and the findings of Wilson (1954) and others. Experience has shown that two meteorologists who have had the opportunity to discuss and jointly classify several locations will not usually vary more than one category in subsequent classifications.

\section{Dual installations of precipitation gages}

To further study the effects of wind on precipitation catches, check gages were installed near gages which were known to be at windy locations. These gages were placed at protected sites as near as possible to the regular installations. Descriptions of some of the dual gages are given below and Table 3 is a tabulation of comparative readings.

(A) Farmington Parrish Creek, Utah. (8080 ft) This gage is located near the top of a mountain ridge and near the head of a canyon with a westerly orientation. Classification of the station is "very windy." The check gage was installed at approximately the same elevation but off to the side of the canyon and in a location "fairly well protected" by surrounding trees.

(B) Mammoth Ranger Station, Utah. (8600 ft) The regular gage is installed in a mountain pass with an exposure classified as "windy." The check gage was located just off the pass at approximately the same elevation and at a "fairly well protected" site.

(C) Hinkey Summit, Nev. (8250 ft) The Hinkey Summit gage is located in a "very windy" location on the extreme top of a mountain ridge. The check gage was placed at a ranch near the mountain pass at a lower elevation $(7500 \mathrm{ft})$ with an exposure classification of "protected."

(D) Richfield, Utah. (5300 ft) The regular gage is located at a radio transmitting station in a flat, open area southeast of town. The exposure classification is "windy." Comparison of records with nearby stations by the double-mass analysis technique showed that the present record was comparatively less than a record. previously recorded in the city at a "protected" site. The check gage was established in a "well-protected" site $2500 \mathrm{ft}$ from the regular gage. An analysis of the terrain would indicate the precipitation at the two sites should be comparable.

\section{Windshields}

Early investigators recognized the problem of wind effects on precipitation catches and developed windshields to minimize these adverse effects (Alter, 1937). Later investigators, (Warnick, 1953), have shown that the windshields provide protection for the lighter wind speeds only (up to $15 \mathrm{mph}$ ). A protected site may occasionally have wind speeds associated with precipitation that might affect the catch and it would seem advisable that all gages in mountainous areas should have shields. Although a windshield would not completely overcome the adverse effects of a poor exposure, it does in general decrease the wind effects. It is necessary that the windshield be properly installed with respect to the gage orifice if maximum value is to be realized (Warnick, 1953).

An excellent example to demonstrate the effectiveness of a windshield may be shown by the records from the recording and standard rain gages of Climax, Colo. As shown in Fig. 1, the recording rain gage was origi-

TABLE 3. Comparative readings for dual installations of precipitation gages.

\begin{tabular}{|c|c|c|c|c|c|c|}
\hline Station & $\begin{array}{l}\text { Station } \mathrm{ga} \\
\text { Period of record }\end{array}$ & $\begin{array}{l}\text { Total } \\
\text { precipi- } \\
\text { tation }\end{array}$ & Period of record & $\begin{array}{l}\text { Total } \\
\text { precipi- } \\
\text { tation }\end{array}$ & $\begin{array}{l}\text { Incre } \\
\text { Amount } \\
\text { (inches) }\end{array}$ & $\begin{array}{l}\text { in catch } \\
\text { Per cent of } \\
\text { station gage } \\
\text { total }\end{array}$ \\
\hline Mammoth Ranger Station, Utah & $\begin{array}{c}2 \text { Dec } 1959 \text { to } \\
1 \text { Jul } 1960\end{array}$ & 18.82 & Same & 21.27 & 2.45 & 13 \\
\hline Hinkey Summit, Nev. & $\begin{array}{l}10 \text { Jul } 1959 \text { to } \\
9 \text { Jun } 1960\end{array}$ & 12.63 & $\begin{array}{l}17 \text { Sep } 1959 \text { to } \\
9 \text { Jun } 1960\end{array}$ & 22.89 & 10.26 & 81 \\
\hline . & $\begin{array}{c}26 \text { Sep } 1960 \text { to } \\
7 \text { Jun } 1961\end{array}$ & 15.66 & $\begin{array}{c}20 \text { Sep } 1960 \text { to } \\
7 \text { Jun } 1961\end{array}$ & 19.41 & 3.78 & 24 \\
\hline Richfield, Utah & $\begin{array}{l}\text { Nov } 56 \text { to Apr } 57 \\
\text { Oct } 57 \text { to Apr } 58 \\
\text { Oct } 58 \text { to Apr } 59 \\
\text { Oct } 59 \text { to Apr } 60 \\
\text { Oct } 60 \text { to Mar } 61\end{array}$ & $\begin{array}{l}5.31 \\
4.97 \\
3.06 \\
4.49 \\
4.65\end{array}$ & $\begin{array}{l}\text { Same } \\
\text { Same } \\
\text { Same } \\
\text { Same } \\
\text { Same }\end{array}$ & $\begin{array}{l}6.62 \\
6.27 \\
3.70 \\
4.69 \\
5.14\end{array}$ & $\begin{array}{l}1.31 \\
1.30 \\
0.64 \\
0.20 \\
0.54\end{array}$ & $\begin{array}{r}25 \\
26 \\
21 \\
4 \\
12\end{array}$ \\
\hline Farmington Parrish Creek, Utah & $\begin{array}{l}28 \text { Aug } 1959 \text { to } \\
27 \text { Jul } 1960 \\
27 \text { Jul } 1960 \text { to } \\
28 \text { Jul } 1961\end{array}$ & $\begin{array}{l}23.42 \\
20.70\end{array}$ & $\begin{array}{l}31 \text { Aug } 1959 \text { to } \\
\text { 31 Jul } 1960 \\
\text { 31 Jul } 1960 \text { to } \\
31 \text { Jul } 1961\end{array}$ & $\begin{array}{l}29.85 \\
24.89\end{array}$ & $\begin{array}{l}6.43 \\
4.19\end{array}$ & $\begin{array}{l}27 \\
20\end{array}$ \\
\hline
\end{tabular}




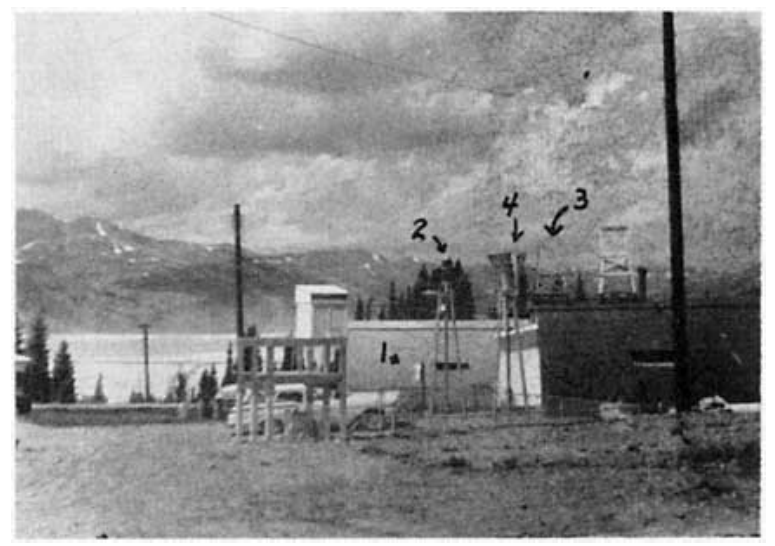

FIG. 1. Weather Station at Climax 2N, Colorado. Picture taken in October 1957 shows old and new locations of recording and non-recording precipitation gages. (1) Old location on ground of non-recording gage. (2) New location on tower of non-recording gage. (3) Old location on tower of recording gage. (4) New location on tower of recording gage.

nally located about $13 \mathrm{ft}$ above the ground on a fourlegged tower and equipped with a windshield. The standard gage was originally located with the orifice $6.5 \mathrm{ft}$ above the ground and protected by surrounding objects. Although the location is "fairly well-protected" from general winds by the surrounding terrain, the wind effect was different on the two gages. The catch during the October-April period was approximately the same during the four seasons from 1953 through 1957 (recording rain gage, 53.50 inches; standard gage, 51.74). Summer readings during this same period (MaySeptember) were also approximately the same (37.79 compared to 36.86 inches).

In October 1957, the standard gage was moved from the ground location to a tower the same height as that for the recording rain gage. Records for the three winter seasons since the move show a marked reduction in the standard rain gage (unshielded) catch in comparison with that for the recording rain gage (shielded) (36.48 compared to 46.25). Summer catches for the same period show that the catches were comparable $(22.39 \mathrm{com}$ pared to 22.49).

The move of the standard rain gage from the protection offered by the nearby buildings to the level of the recording gage subjected it to the slightly higher winds. The reduction in catch of the standard gage gives an indication of the difference in catch when shielded and unshielded gages are subjected to light winds during the winter season. The comparable summer readings for the gages before and after the move show that the difference in wind effect for different exposures was not measurable during the period when precipitation was principally in the form of rain.

\section{Recommendations}

If we are to make maximum use of precipitation records, additional research relative to precipitation gage exposure is essential and an objective system for classifying gage exposure is needed. Until enough information is available for the development of a standard objective classification procedure, the utilization of a subjective system should prove beneficial.

Every effort should be made to keep the descriptions of gage locations, given in station histories, as complete and as up-to-date as possible. The information in the station histories could be used to some advantage in the development of an objective exposure classification system. In addition, they provide supplemental information which would be of value in the analysis of past weather records.

\section{REFERENCES}

Alter, J. C., 1937: Shielded storage precipitation gages. Mon. Wea. Rev., 65, 262-265.

Black, R. F., 1954: Precipitation at Barrow, Alaska, greater than recorded. Trans. Amer. geophys. Union, 35, 203-207.

Bruce, J. P., and J. G. Potter, 1957: The accuracy of precipitation measurements. Proc., Third National Meeting, Royal Meteor. Soc., Canadian Branch, Toronto, Canada, 1-15.

Codd, Ashton R., 1959: The photocanopyometer. Proc. Western Snow Conf., 27th Annual Meeting, Reno, Nev., 17-21. (May be obtained from Secretary of the Western Snow Conference, Allen West, Pacific Southwest Forest and Range Experiment Station, P. O. Box 245, Berkeley 1, Calif. $\$ 2.00$.)

Warnick, C. C., 1953 : Experiments with windshields for precipitation gages. Trans. Amer. geoplys. Union, 34, 379-388.

Wilson, W. T., 1954: Analysis of winter precipitation observations in the cooperative snow investigations. Mon. Wea. Rev., 82, 183-195. 